Regular Research Article

\title{
Classification Methods for Mapping Mangrove Extents and Drivers of Change in Thanh Hoa Province, Vietnam during 2005-2018
}

\author{
Hai-Hoa Nguyen ${ }^{1, *}$, Nghia Huu Nghia ${ }^{1}$, Hien Thi Thu Nguyen ${ }^{2}$, An Thanh Le ${ }^{1}$, Lan Thi Ngoc Tran ${ }^{1}$, Linh Vo \\ Khanh Duong ${ }^{1}$, Simone Bohm ${ }^{3}$, Michael J Furniss ${ }^{4}$ \\ 1 Vietnam National University of Forestry, Vietnam \\ 2 Thai Nguyen University of Agriculture and Forestry, Vietnam \\ 3 University of Hohenheim, Germany \\ 4 Humboldt State University, USA \\ * Correspondence author: hoanh@vnuf.edu.vn
}

\begin{abstract}
Mangrove forests have been globally recognised as their vital functions in preventing coastal erosion, mitigating effects of wave actions and protecting coastal habitats and adjacent shoreline land-uses from extreme coastal events. However, these functions are under severe threats due to the rapid growth of population, intensive shrimp farming and the increased intensity of severe storms in Hau Loc and Nga Son districts, Thanh Hoa province. This research was conducted to monitor spatial-temporal changes in mangrove extents using Landsat and Sentinel imageries from 2005 to 2018. Unsupervised and supervised classification methods and vegetation indices were tested to select the most suitable classification method for study sites, then to quantify mangrove extents and their changes in selected years. The findings show that supervised classification was the most suitable in study sites compared to vegetation indices and unsupervised classification. Mangrove forest extents increased by $7.5 \%, 38.6 \%$, and $47.8 \%$ during periods of 2005 - 2010, 2010 - 2015 and 2015 - 2018, respectively. An increase of mangrove extents resulted from national programs of mangrove rehabilitation and restoration during 2005- 2018, increased by 278.0 ha (123.0\%).
\end{abstract}

Keywords: Mangrove; restoration; remote sensing; spatio-temporal; vegetation

\section{Introduction}

Mangrove forests are among the most productive ecosystems on this planet (Ramdani et al., 2018) providing a wide range of ecological and economic products and services, and supporting a rich and diverse coastal and marine ecosystems (Viswanathan et al., 2011; Salem and Mercer, 2012; Van Lavieren et al., 2012). Over the past five decades, discussions of mangrove ecosystems and management have focused on: the ability to fix, store and mineralise carbon; nursery functions; shoreline protection; and their land-building capacity (Field et al., 1998; Viswanathan et al., 2011; Lee et al., 2014; Peneva-Reed, 2014). Mangrove forests are more likely to be disturbed by natural events, such as typhoons and floods. However, nearly all of mangrove forests have experienced with significant losses in recent decades under economic and population pressure to meet continually growing demands for aquaculture and fishing farming. World population growth is expected to peak at 9.22 billion in 2075 (Exner et al., 2013), leading to increasing pressure from human activities, including over-harvesting, aquaculture and coastal development (Viswanathan et al., 2011). Despite existing rules, regulations and policies, the management and protection of mangrove resources are still weak and lacking linkage among sectors. Few research studies have brought specific solutions and practices. It is estimated that about one-fifth of all mangrove forests have been lost since 1980 and many remaining mangrove forests are being considered to be degraded (Van Lavieren et al., 2012). Although the annual global rate of mangrove forest loss declined from just over $1.0 \%$ in the 1980 s to $0.66 \%$ between 2000 and 2005, it was 3- 5 times higher than the average rate of loss of all forests (Duke et al., 2014). As a sample, the Vietnam War (1962-1971) resulted in the destruction of nearly $40 \%$ of mangrove forests in Southern Vietnam (Hong and San, 1993).

Thanh Hoa province is located in the North Central region of Vietnam. The province has $102 \mathrm{~km}$ 
of the coastline long, wetlands and coastal mangrove forests of 1195.5 ha in 2018 . Thanh Hoa province is considered to have a high potential for planning, restoration, and development of mangrove forests, promoting local livelihoods. However, due to the shortage of investigation and studies in the mangrove sites, there is little information about mangrove forests in this province.

In the last three decades, spatial technology has evolved dramatically to include a suite of sensors operating at a wide range of imaging scales and potential application (Rogan and Chen, 2004). The remote sensing and GIS technologies are powerful tools enabling the capture, storage, analysis and management of spatially referenced data. In the present study, remote sensing is an applicable and accurate tool to investigate changes in forest extents (Singh, 1989; Lu et al., 2004). It is difficult to reach and penetrate mangrove forests along coastal areas by using conventional investigation methods (Green et al., 1998; Dat et al., 2000; Wang et al., 2003), but remote sensing technology has offered a special utility. More importantly, Geographic Information System (GIS) and remote sensing data have not been used extensively for wetland covers mapping in Thanh Hoa province, in particular mangrove forests. This study was to quantify the extent of mangrove forests and recent changes for the whole coastline of Thanh Hoa province for four selected years (2005, 2010, 2015 and 2018), to understand mangrove dynamics over the last 13 years. Available multitemporal Landsat and Sentinel imageries and Land Use/Land Cover (LULC) maps were used to construct thematic maps by testing various approaches, including Supervised Classification, Unsupervised classification, NDVI, SAVI, MSAVI, IPVI, DVI, GNDV, BNDV, OSAVI, TVI, and EVI. Study then selected the most suitable classification method for study sites, based on the accuracy assessments. The study then identified drivers of changes in mangrove extents and suggested feasible solutions for enhancing mangrove management.

\section{Materials and Methods}

\subsection{Study site}

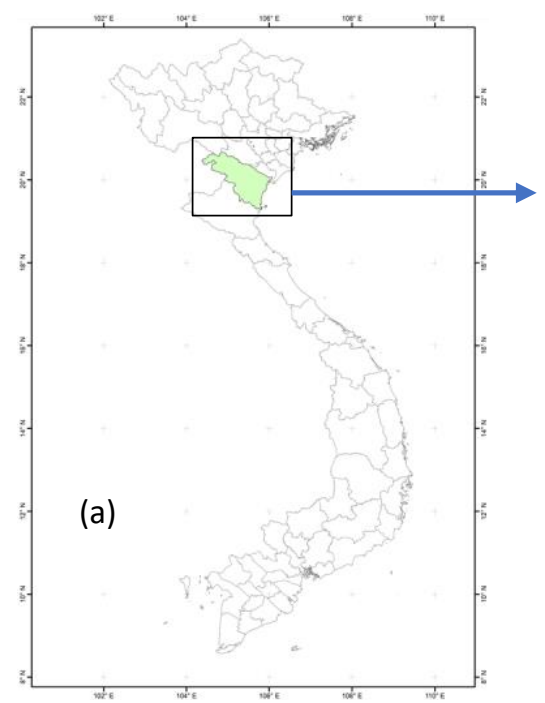

(b)

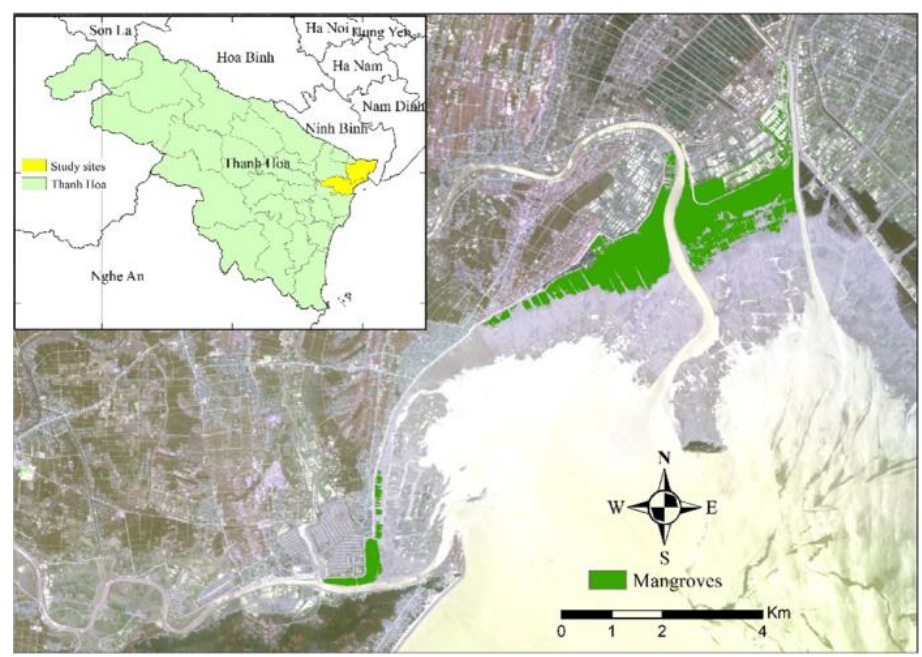

Figure 1. Study sites with mangrove distribution: (a) Geographic location of Thanh Hoa in Vietnam; (b) Study sites in Thanh Hoa province. 
Thanh Hoa is located in the North Central region, $150 \mathrm{~km}$ south away from Hanoi, and 1,560 $\mathrm{km}$ from Ho Chi Minh City. It borders three provinces, including Son La, Hoa Binh, Ninh Binh provinces to the North, Nghe An province to the South, Laos to the West and the Gulf of Tonkin to the East. It has a tropical monsoon climate that is influenced by both the temperate climate of the Gulf of Tonkin and the North Central Coast. Thanh Hoa faces an average of six to eight typhoons annually. In this study, two districts, including Nga Son and Hau Loc, were selected due to their abundant coastal mangrove forests in Thanh Hoa province (Figure 1). Temperature varies from 20 to $28^{\circ} \mathrm{C}$ throughout the year. The average annual rainfall is $1,800 \mathrm{~mm}$, with a distinct dry and rainy season. While extreme storms and ocean conditions resulting from climate change are uncertain in magnitude, the physics and modelling of climate indicates that floods and droughts are becoming increasingly common and intensified (Raghavan et al., 2015; Jiang et al., 2018).

\subsection{Methods}

The details of image classification methods used for mapping mangrove extents are schematically illustrated in the Figure 2.

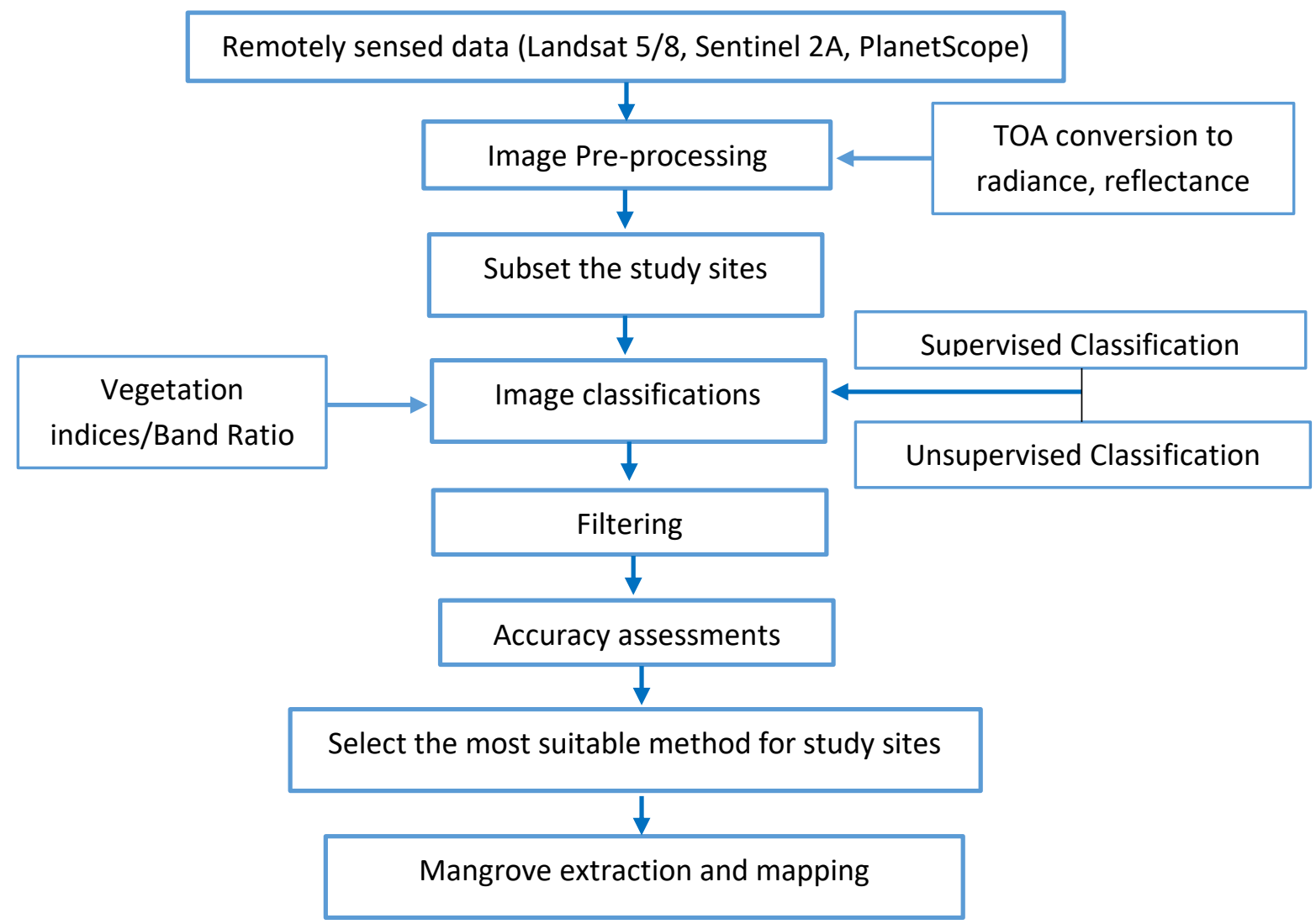

Figure 2. Flow chart of methodology for mapping mangrove extents.

\subsubsection{Data collection}

The study was conducted using Landsat 5, Landsat 8 and Sentinel 2A multi-spectral imageries covering the areas of Nga Son and Hau Loc districts, Thanh Hoa province. The details of multitemporal Landsat images (2005- 2015) and Sentinel images (2015- 2018) were used to detect mangrove extents and the change (Table 1 ). 
Table 1. Remotely sensed images collected and used in the study.

\begin{tabular}{clccc}
\hline ID & \multicolumn{1}{c}{ Image codes } & Date & Resolution (m) & Remarks \\
\hline 1 & LT05_L1TP126046_20050511_20161126 & $05 / 11 / 2005$ & 30 & Landsat 5 \\
2 & LT05_L1TP126046_20101203_20161012 & $03 / 12 / 2010$ & 30 & Landsat 5 \\
3 & LC08_L1TP127046_20150701_20170407 & $01 / 07 / 2015$ & 30 & Landsat 8 \\
4 & S2A_L1C_T48QWH_20151022T034524 & $22 / 10 / 2015$ & 10 & Sentinel 2A \\
5 & S2A_L1C_T48QWH_20180409T033500 & $09 / 04 / 2018$ & 10 & Sentinel 2A \\
6 & 20170603_024225_1004_3B_AnalyticMS & $03 / 06 / 2017$ & 3 & PLanetScope \\
& 20170603_024215_1013_3B_AnalyticMS & $03 / 06 / 2017$ & 3 & PlanetScope \\
& 20170603_024214_1013_3B_AnalyticMS & $03 / 06 / 2017$ & 3 & PlanetScope \\
7 & Land cover maps & $2005,2010,2015$ & $1: 50,000^{a}$ & Thanh Hoa \\
\hline
\end{tabular}

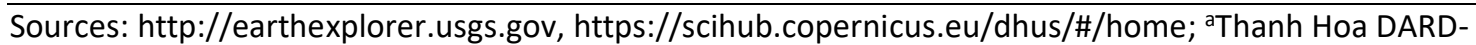
Department of Agriculture and Rural Development (2018); https://www.planet.com/explorer

One of the most coastally important features is aware before selecting remote sensing images for mangrove mapping is the tidal cycle, tidal inundation and cloud cover. These factors may have the potential to significantly bias the mangrove mapping results (Zhang et al., 2019). Fortunately, the optical remote sensing data, including Landsat and Sentinel data, offers time-series remotely sensed images, which provide more options to avoid the effects of tidal inundation on the accuracy of mangrove mapping (Zhang et al., 2017; Zhang et al., 2019). In addition, the knowledge of tidal levels at the time of remotely sensed images acquired is also paid attention to eliminate the effects of tidal levels at various observation as well (Chen et al., 2017). In this study, the low tidal inundation imageries in consultation with the tidal tables together with information of local tidal regimes obtained from local people during the field survey were prioritised to select for mangrove mapping.

A literature review was attempted to collect secondary data, including published documents, peer-reviewed papers and associated reports. The secondary data collected from this study include coastal land use land cover maps; Geographic information system layers; Socio-economic conditions of the study site; data related to the dynamics of coastal mangrove forests; relevant policies, legal documents to mangrove forests; socioeconomic reports from communes in the research location.

Field survey was conducted to collect ground information on land use and land cover, including mangrove forests, water bodies and non-mangrove plants. By using a Garmin $650 \mathrm{GPS}$, a total of 600 GCPs (Ground Control Points) were mainly collected from both squared-shape patches and random points of mangrove forests and other non-mangrove plants to gain more ground information for separating mangrove forests from other non-mangrove covers. In particular, there were $300 \mathrm{GCPs}$ collected for mangrove forests, $100 \mathrm{GCPs}$ for water bodies and $200 \mathrm{GCPs}$ for others (including bare soil, settlements, mudflats, beaches and non-mangrove plants).

Primary data in this study was mainly obtained from semi-structured interviews. A total of 50 people were randomly selected to collect information in Nga Son and Hau Loc districts, among diverse groups of local authorities, forest management agencies, and local people, including 10 forest rangers, 10 local guards; 20 local people and 10 local authorities from People's Committee at district as well as commune levels. Local people were selected who have been living nearby mangroves for a long time, so they understand very well about the past and current mangrove management and changes.

\subsubsection{Data pre-processing}

In this study, all Landsat images were required to radiometric calibration. Gain bias correction scattering effects and correction of the sun angle are very necessary as mangrove cover analysis and change detection were carried out (e.g. Song et al., 2001; Norjamaki and Tokola, 2007; Gupta et al., 2018). Radiometric calibration of Landsat Bands was conducted to convert digital number values into top of the atmosphere spectral radiance (TOA), then Bands were converted to TOA planetary 
reflectance (Gupta et al., 2018). Atmospheric and radiometric corrections were applied to remove errors and to increase accuracies using Spatial Analyst Tools in ArcGIS 10.4.1 (Hai-Hoa, 2016).

In addition, five Bands (Blue, Green, Red, NIR and SWIR) for both Sentinel and Landsat imageries were used for all classification and interpretation techniques (Table 1). All Bands were stacked into composite images, then were subsequently masked to both include areas where mangrove forests are more likely to distribute, such as low-lying areas and intertidal zones; and exclude areas where mangrove forests do not naturally occur as far inland, highlands and open ocean (Long and Giri, 2011). Masking possible mangrove areas was conducted to reduce unnecessary data volume and increase overall classification accuracy. In order to mask possible mangrove areas accurately, higher spatial resolution images in this study, including PlanetScope $(3 \mathrm{~m} \times 3 \mathrm{~m})$ and Google Earth were used to delineate the boundary of possible mangrove areas from other land use and land cover types. The delineated boundary was then checked with the field survey to ensure every possible mangrove areas were included within the boundary. Remarkably, mangrove forests in the study sites are separated from other land use and land cover types by the dyke system. Therefore, there was no difficulty in delineating the boundary of possible mangrove areas in the study sites. In addition, the 30-m SRTM DEM data, their derived slope and elevation were employed to mask out the regions of high elevation and steep-slope where mangrove forests are not likely to occur (Chen et al., 2017).

\subsubsection{Data processing and image classification}

Image classification was conducted to map mangrove extents in 2018 by testing 12 vegetation indices (including SR, NDVI, SAVI, MSAVI, GNDVI, BNDVI, OSAVI, DVI, IPVI, EVI, NBR, TVI), Supervised and Unsupervised Classification approaches (Table 2). In the combination with GCPs (Ground control points), the accuracy was then assessed using the ground-truthing information in 2018. The method with the highest accuracy was then selected to construct mangrove forests mapping in 2005,2010 and 2015. Two map layers then were overlaid to detect the changes in mangrove extents in each selected period, namely 2005-2010, 2010-2015, 2015-2018.

Vegetation indices calculation: In this study, 12 vegetation indices were tested and used to quantify mangrove extents (Table 2).

Unsupervised classification: Imageries were processed with the Supervised Classification approach. The study applied the k-means clustering algorithm to produce 30 user-defined classes with the iteration number of 5 . The generated classes were then compared with the field survey data and merged them into 3 main classes, namely mangrove forests, water surface and others (bare soil, settlements, mudflats, beaches and non-mangrove plants).

Supervised classification: This study employed the Supervised Classification approach by using the Maximum Likelihood Classification. The training samples were selected from PlanetScope imageries in 2017 in comparison with Google Earth images, Sentinel 2A and the field survey data. The total number of training samples selected were 30,20 and 15 for mangrove forests, water surface and others, respectively. Number of pixels for each sample were ensured to be taken as minimum of 50 for the accuracy matter.

Accuracy assessments: A total of $300 \mathrm{GCPs}$ (Ground Control Points), out of $600 \mathrm{GCPs}$ were randomly selected and used to perform accuracy assessments using other high resolution images, such as Google Earth and 2017 PlanetScope imageries for the 2018 classified image (Table 1). Additional field data collection on mangrove locations was also conducted to provide more information in relation to the possible occurrence of mangrove forests. The validation points were applied to extract land cover classes from 2018 classified map in ArcGIS, a confusion matrix was then created with the image classified and ground survey classes. For other years of 2005, 2010 and 2015, associated Google Earth images were used to perform accuracy assessments. In addition, reference maps (land cover maps in 2005, 2010 and 2015 with scale of 1:50,000) as well as local knowledge regarding land use/land over were also used to increase accuracies of mangrove mapping. 
Table 2. Equations of vegetation indices used for estimating mangrove extents.

\begin{tabular}{|c|c|c|c|}
\hline ID & $\begin{array}{l}\text { Classification } \\
\text { methods }\end{array}$ & Equations & References \\
\hline I. & \multicolumn{3}{|c|}{ Vegetation indices/Band ratio } \\
\hline 1.1 & $\begin{array}{l}\text { SR } \\
\text { (Simple Ratio) }\end{array}$ & NIR/RED & $\begin{array}{l}\text { Batadlan et al., (2009); Kongwongjan et } \\
\text { al., (2012); Dat et al., (2018) }\end{array}$ \\
\hline 1.2 & $\begin{array}{l}\text { NDVI } \\
\text { (Normalised } \\
\text { Difference } \\
\text { Vegetation Index) }\end{array}$ & $(\mathrm{NIR}-\mathrm{RED}) /(\mathrm{NIR}+\mathrm{RED})$ & $\begin{array}{l}\text { Saleh (2007); Ramdani et al., (2018); Dat } \\
\text { et al., (2018) }\end{array}$ \\
\hline 1.3 & $\begin{array}{l}\text { GNDVI } \\
\text { (Green Normalised } \\
\text { Difference } \\
\text { Vegetation Index) }\end{array}$ & $(\mathrm{NIR}-\mathrm{GREEN}) /(\mathrm{NIR}+\mathrm{GREEN})$ & Muhsoni et al., (2018) \\
\hline 1.4 & $\begin{array}{l}\text { BNDVI } \\
\text { (Blue Normalised } \\
\text { Difference } \\
\text { Vegetation Index) }\end{array}$ & (NIR-BLUE)/(NIR+BLUE) & Wang et al., (2007) \\
\hline 1.5 & $\begin{array}{l}\text { SAVI } \\
\text { (Soil Adjusted } \\
\text { Vegetation Index) }\end{array}$ & $\{(\mathrm{NIR}-\mathrm{RED}) /(\mathrm{NIR}+\mathrm{RED}+\mathrm{L})\}^{*}(1+\mathrm{L})$ & $\begin{array}{l}\text { Kongwongjan et al., (2012); Dat et al., } \\
\text { (2018) }\end{array}$ \\
\hline 1.6 & $\begin{array}{l}\text { OSAVI } \\
\text { (Optimised Soil } \\
\text { Adjusted vegetation } \\
\text { Index) }\end{array}$ & $(1+0.16) *\{(\mathrm{NIR}-\mathrm{RED}) /(\mathrm{NIR}+\mathrm{RED}+0.16\}$ & Batadlan et al., (2009) \\
\hline 1.7 & $\begin{array}{l}\text { MSAVI } \\
\text { (Modify Soil Adjusted } \\
\text { Vegetation Index) }\end{array}$ & $\begin{array}{l}\frac{1}{2}\{(2 N I R+1) \\
-\sqrt{(2 N I R+1)^{2}-8(N I R-R E D)}\end{array}$ & Dat et al., (2018) \\
\hline 1.8 & $\begin{array}{l}\text { DVI } \\
\text { (Difference } \\
\text { Vegetation Index) } \\
\text { IPVI }\end{array}$ & NIR - RED & $\begin{array}{l}\text { Batadlan et al., (2009); Kongwongjan et } \\
\text { al., (2012); Dat et al., (2018) }\end{array}$ \\
\hline 1.9 & $\begin{array}{l}\text { (Infrared Percentage } \\
\text { Vegetation Index) } \\
\text { EVI2 }\end{array}$ & $N I R /(N I R+R E D)$ & Kongwongjan et al., (2012) \\
\hline 1.10 & $\begin{array}{l}\mathrm{EVI} 2 \\
\text { (Enhanced } \\
\text { Vegetation Index) }\end{array}$ & $2.5 *\{(\mathrm{NIR}-\mathrm{RED}) /(\mathrm{NIR}+2.4 * \mathrm{RED}+1)\}$ & Dat et al., (2018) \\
\hline 1.11 & $\begin{array}{l}\text { NBR } \\
\text { (Normalised Burn } \\
\text { Ratio) }\end{array}$ & (NIR-SWIR)/(NIR+SWIR) & Li et al., (2013) \\
\hline 1.12 & $\begin{array}{l}\text { TVI } \\
\text { (Triangular } \\
\text { Vegetation Index) }\end{array}$ & $\begin{array}{l}0.5 *\{120 *(\text { NIR-GREEN })\}-200 *(\text { RED }- \\
\text { GREEN) }\end{array}$ & $\begin{array}{l}\text { Kongwongjan et al., (2012); Muhsoni et } \\
\text { al., (2018) }\end{array}$ \\
\hline II. & Supervised Classificat & & $\begin{array}{l}\text { Peneva-Reed, (2014); Dat et al., (2018); } \\
\text { Islam et al., (2018) }\end{array}$ \\
\hline III. & Unsupervised Classific & tion & $\begin{array}{l}\text { Dat et al., (2000); Saleh (2007); Hai-Hoa } \\
\text { (2016) }\end{array}$ \\
\hline
\end{tabular}

\section{Results and discussions}

\subsection{Spatial-temporal mangrove extents and management}

PlanetScope imageries with the spatial resolution of $3 \mathrm{~m} \times 3 \mathrm{~m}$ were used to assist in assessing mangrove mapping accuracies, while Sentinel 2A in 2018 was used to construct the status map of mangrove forests using SCM, UCM and vegetation indices (IPVI, DVI, GNDVI, BDVI, OSAVI, TVI, EVI, 
SAVI, NDVI, NBR, SR, and MSAVI). The accuracy assessments of mangrove classifications in 2018 are presented in Table 3.

Table 3. Accuracy assessments of mangrove mapping using different classification methods.

\begin{tabular}{cccccc}
\hline ID & $\begin{array}{c}\text { Classification } \\
\text { methods }\end{array}$ & Man (ha) & $\begin{array}{c}\text { Water bodies } \\
\text { (ha) }\end{array}$ & Others (ha) & Accuracies (\%) \\
\hline 1 & IPVI & 509 & 625 & 1131 & 83.4 \\
2 & DVI & 508 & 560 & 1197 & 85.7 \\
3 & GNDVI & 487 & 609 & 1169 & 78.2 \\
4 & BDVI & 470 & 509 & 1286 & 72.4 \\
5 & OSAVI & 474 & 618 & 1173 & 84.3 \\
6 & TVI & 487 & 521 & 1257 & 79.9 \\
7 & EVI & 474 & 619 & 1172 & 84.1 \\
8 & SCM & 501 & 616 & 1149 & 90.0 \\
9 & SAVI & 564 & 625 & 1076 & 81.2 \\
10 & NDVI & 509 & 520 & 1237 & 80.8 \\
11 & NBR & 252 & 818 & 1196 & 65.1 \\
12 & SR & 246 & 569 & 1451 & 75.9 \\
13 & MSAVI & 181 & 575 & 1510 & 62.5 \\
14 & UCM & 512 & 598 & 1155 & 85.0 \\
\hline
\end{tabular}

Man (Mangrove forests); Others (Bare soils, settlements, non-mangrove plants, mudflats)

In general, accuracy assessments of all classification methods are greater than $60.0 \%$ in overall accuracy. Particularly, SCM has the highest accuracy among other methods, around $90.0 \%$, followed by the DVI, SCM, OSAVI, EVI, IPPVI, SAVI, NDVI, TVI, GNDVI, SR, BDVI, NBR, and MSAVI at $85.7 \%$; $85.0 ; 84.3 ; 84.1 ; 83.4 ; 81.2 ; 80.8 ; 79.9 ; 78.2 ; 75.9 ; 72.4 ; 65.1$; and $62.5 \%$, respectively (Table 3 ). Similarly, many studies have confirmed that NDVI is one of the most common classification methods and it is often used to map mangrove extents in particular (Saleh, 2007; Alsaaideh et al., 2013; Ramdani et al., 2018; Dat et al., 2018), whereas EVI, SCM, IPVI, DVI, OSAVI, SAVI and UCM are less likely to be used (Gupta et al., 2018). However, these indices and methods have offered higher accuracies than NDVI in this study. SCM especially provides the highest accuracy and thus it was selected to quantify mangrove extents in Hau Loc and Nga Son districts. This method also has been used for mapping mangrove forests in others studies, such as Kongwongjan et al., (2012); Islam et al., (2018).

\subsubsection{Current status of mangrove forests:}

Based on 2018 field survey in combination with national forest inventory in 2017, this study has identified the spatial distribution of mangrove species (Figure 3). In Nga Son and Hau Loc districts, mangrove species compositions are relatively simple with just 3 species, namely $S$. caseolaris, $A$. corniculatum, and $K$. candel. Their structures and spatial distribution differ from each other. $A$. corniculatum is the dominant species in Nga Son district and it was planted in 1985, 1997, 2000, 2013 and 2015 in Nga Tan and Nga Thuy communes particularly (Figure 3). Differently, in Hau Loc district, mangrove seedlings have mainly distributed in Hai Loc and Da Loc communes with two dominant species (S. caseolaris, A. corniculatum), while some small areas have been found with mixed mangrove species (S. caseolaris and K. obovata). Both communes have had a series of mangrove forests planted over time, including in 1985, 1997, 1999, 2000, 2004, 2005, 2013, 2014, and 2015. 


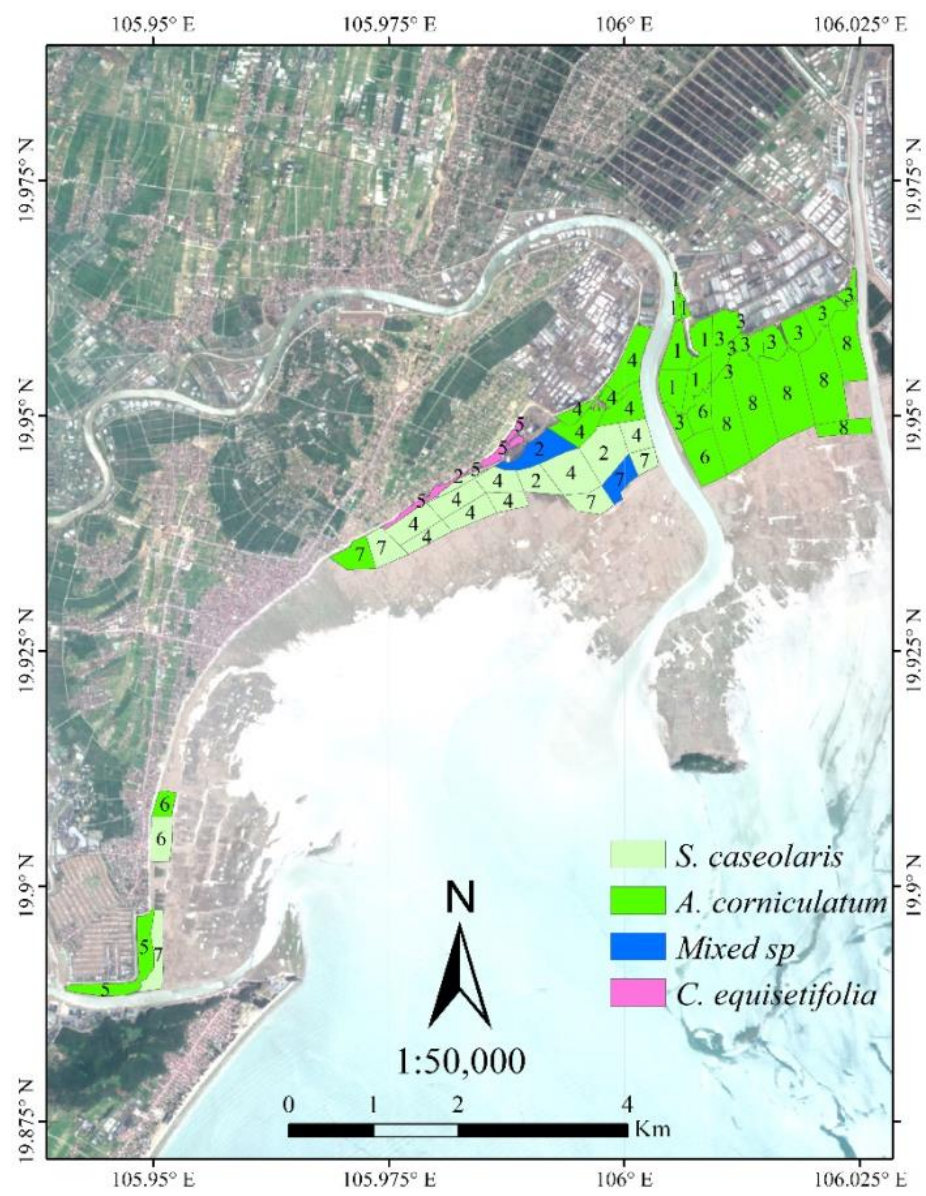

Figure 3. Spatial distribution of coastal mangroves in study areas in 2018: Number 1 refers to the year of mangrove species planted in 1985; 2 (1997); 3 (2000), 4 (2004); 5 (2005); 6 (2013); 7 (2014); number 8 refers to the year of mangrove species planted in 2015.

\subsubsection{Management scheme in mangrove forests:}

Over the years, the Vietnamese government has adopted to and adapted with various approaches to manage forests in general and mangrove forest in particular, including from centralized State-controlled models to cooperative management models, to private management models (Hawkins et al., 2010). Until the mid-1980s, the policy was characterized by a centralized State-Controlled model; forests and forest products were viewed as national assets and owned by the state ( $\mathrm{Ha}$ et al., 2014). Sustainable management of mangrove forests needs an effective combination of scales of jurisdiction and management. The Ministry of Agriculture and Rural Development (MARD) performs as the unified state management over the protection, development, and use of protection forests throughout the country. Similarly, Thanh Hoa People's Committees exercises state management over protection forests in the provincial area at the provincial level. Thanh Hoa Department of Agriculture and Rural Development (DARD) advises the Thanh Hoa People's Committees in performing the state management of protection forests. At district level, Nga Son and Hau Loc Department of People's Committees perform the state management of protection forests. The Commune People's Committees is in charge of managing the protection forest in their respective localities in the following domains:

- Directing, urging and guiding households, individuals and local communities in implementing the legislation on protection and development of protection forests in their regions; 
- Elaborating plans on protection and development of protection forests and scheme on forest allocation and forest lease then submitting them to competent state agencies for approval and implementation;

- Giving protection forests to the allocated or leased local people and identifying the boundaries of protection forests to protect forests in the localities;

- Guiding local communities in elaborating and implementing the regulations on management, protection, and development of protection forests; Organizing and mobilizing the coordination between local people, forest rangers, polices and army to detect and prevent in time acts of encroaching upon protection forests;

- Inspecting and handling of law violation according to its competence;

- Managing protection forest areas un-allocated or unleased in the commune; submit to District People's Committees for use in protection forests areas unallocated or unleashed by the State;

Based on the filed survey, this study agrees with Primavera (2000), Hawkins et al., (2010) that overlapping mandates of the border guard station and local people communities results in a decline of quality and quantity of mangrove forests. There is no direct authority for mangrove management in the study site. For some projects, a group of people in communities formed for monitoring and evaluating the project and thereby vested the local community to take care of it. CMMB proved to be a good solution for local people to manage and take care of mangrove forests (Buffle et al., 2011).

\subsection{Quantification of coastal mangrove extents and drivers of changes}

The mangrove forest extents have experienced with a rapid change in Nga Tien commune (belongs to Nga Son district); Da Loc and Hai Loc communes (belong to Hau Loc district) between 2005 and 2018 by using SCM. The total areas covered by mangrove forests and non-mangrove class (water surface and others) have been shown in Table 4.

Table 4. Changes in mangrove forest extents over the period of 2005- 2018.

\begin{tabular}{lcccccc}
\hline \multirow{2}{*}{ Classes } & \multicolumn{2}{c}{ Mangrove forests } & \multicolumn{5}{c}{ Non-mangrove } \\
\cline { 3 - 7 } Year/Period & $\mathrm{Ha}$ & $\%$ & $\mathrm{Ha}$ & $\%$ & $\mathrm{Ha}$ & $\%$ \\
\cline { 3 - 7 } 2005 & 226 & & 372 & & 1766 & \\
2010 & 246 & & 1413 & & 720 & \\
$2005-2010$ & 20 & 7.5 & 1041 & 279.8 & -1046 & -59.2 \\
2015 & 341 & & 1891 & & 132 & \\
$2010-2015$ & 95 & 38.6 & 478 & 33.8 & -588 & -81.7 \\
2018 & 504 & & 653 & & 1205 & \\
$2015-2018$ & 163 & 47.8 & -1238 & -65.46 & 1073 & $\mathbf{8 1 2 . 9}$ \\
$2005-2018$ & 278 & 123.0 & & & & \\
\hline
\end{tabular}

$(-)$ means the loss of mangrove forests while $(+)$ indicates an increase of mangrove forests in the corresponding period.

As shown in Table 4 that there are changes in mangrove forests and non-mangrove class in three selected periods. It is also important to note that there is a dramatic change in the 'water bodies' and 'others' classes in each period. This change may be explained as the effects of tidal change regimes as various temporal tidal satellite imageries were selected in this study (Zhang et al., 2017; Xia et al., 2018, Tran Thi et al., 2014). On the contrary, mangrove forests have increased sharply in the two first periods and a slower increase in the later period (Figure 4). In particular, mangrove extents have significantly increased by 20 ha, 95 ha and 163 ha in the period of 2005- 
2010, 2010- 2015 and 2015- 2018, respectively.

3.2.1 Identification of drivers of mangrove changes during 2005- 2018:

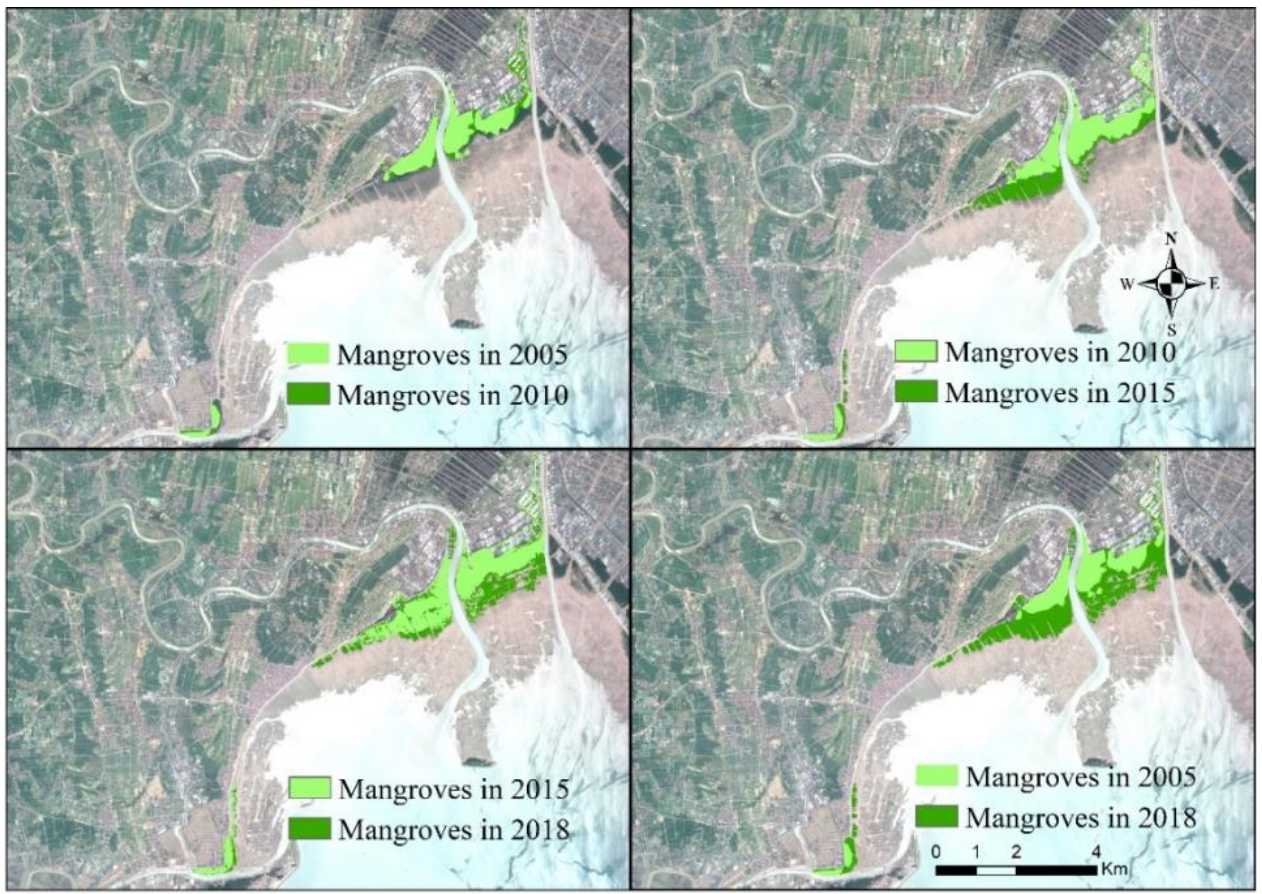

Figure 4. Changes in mangrove extents over the period of 2005- 2018.

As shown in Figure 3 and Table 4 in combination with the field survey, key drivers of changes in mangrove forests followed by the studied periods are summarised as below:

\section{During the period of 2005-2010:}

In 1989, the Government of Vietnam along with international organizations, such as the Japanese Red Cross and Save the Children collaborated to plant 350 ha of mangrove seedlings in offshore areas bordering Da Loc commune (belongs to Hau Loc district), but with a disappointing survival rate of 15-20\% within one year (Hoa et al., 2012). After this, there were several additional planting projects from NGOs (Non- Government Organizations) and the Vietnam government, but the rate of seedling survival was still low until 2005. Remarkably, the period of 2005- 2010 was witnessed with a significant increase in mangrove extents, estimated at about 20.0 ha with an increasing rate of $7.5 \%$. In particular, in 2005, the Red Cross of Vietnam, with support from the International Federation, the Japanese Red Cross Society and the Danish Red Cross planted mangrove forests for disaster risk management in response to damage to the commune from typhoon Damrey (International Federation of Red Cross and Red Crescent Societies, 2011). Since then, the local community has recognised the importance of mangrove forests in protecting their villages and stabilising their livelihoods.

Despite the importance of mangrove forests acknowledged, mangrove deforestation was still prevalent due to the increasing demand for lumber and fuel (Richards and Friess, 2016; Agarwal et al., 2019). In addition, external factors, such as storms, climate change, tidal extremes, pests, and diseases, have also led to the reduction of mangrove forests in the study areas (Reed, 2015). Interviews with local people also confirmed that large areas of mangrove forests were destroyed and degraded by the storms and associated shrimp farm activities. Consequently, nearby coastal creatures, such as crabs and fishes have been significantly reduced. However, during this period, a community-based approach to mangrove management was adopted to replant and restore 
mangrove forests. These efforts were contributed to a success rate of $70 \%$ to $90 \%$ in 2009, compared to 15.0 \% in 1989 (Hong and San, 1993; Hai-Hoa, 2014).

During the period of 2010-2015:

Mangrove extents were recorded as an increase of additional 95 ha (equivalent to $38.6 \%$ of total mangrove areas). This area was recorded as approximately five times higher than during the period of 2005- 2010. It was clearly observed that an obvious increase in mangrove forests since CMMB (Community-based Mangrove Management Board) was established with participation of local governments, representatives of various organizations (Women's Union and Fatherland Front), and local farmers in mangrove restoration and development projects (Buffle et al., 2011).

Table 5. Past and present mangrove projects in Thanh Hoa province.

\begin{tabular}{|c|c|c|c|c|}
\hline No. & Projects & Timeline & $\begin{array}{l}\text { Project scale } \\
\text { (ha) }\end{array}$ & Project site \\
\hline 1 & $\begin{array}{l}\text { Planting coastal protection } \\
\text { mangroves against coastal erosion } \\
\text { in Thanh Hoa province (Climate } \\
\text { Change Adaptation Fund) }\end{array}$ & 2014-2015 & 300 & $\begin{array}{l}\text { Hau Loc district, Hoang Hoa } \\
\text { district and Sam Son town, } \\
\text { Thanh Hoa province }\end{array}$ \\
\hline 2 & $\begin{array}{l}\text { Mangrove Prevention Program for } \\
\text { Disaster Preparedness (Japanese } \\
\text { Red Cross) }\end{array}$ & $\begin{array}{l}2009- \\
2015\end{array}$ & 2296 & $\begin{array}{c}06 \text { Districts: Nga Son, Hau Loc, } \\
\text { Hoang Hoa, Sam Son, Quang } \\
\text { Xuong, Tinh Gia }\end{array}$ \\
\hline 3 & $\begin{array}{l}\text { Investment project to develop } \\
\text { protective mangroves in coastal } \\
\text { communes of Hau Loc district, } \\
\text { Thanh Hoa province (Central } \\
\text { disaster fund) }\end{array}$ & 2010-2015 & 200 & $\begin{array}{l}\text { Hau Loc district, Thanh Hoa } \\
\text { province }\end{array}$ \\
\hline 4 & $\begin{array}{l}\text { Strengthening the capacity of } \\
\text { resistance to climate change for } \\
\text { vulnerable coastal communities in } \\
\text { Vietnam. }\end{array}$ & Since 2017 & $\begin{array}{l}50 \text { ha in Nga } \\
\text { Son } \\
50 \text { ha in Hau } \\
\text { Loc }\end{array}$ & Nga Son and Hau Loc district \\
\hline 5 & $\begin{array}{l}\text { Modernizing the forestry sector } \\
\text { and enhancing coastal resilience. }\end{array}$ & Since 2017 & $\begin{array}{l}50 \text { ha in } \mathrm{Hau} \\
\text { Loc }\end{array}$ & 6 districts \\
\hline 6 & $\begin{array}{l}\text { Project on planting and restoration } \\
\text { of coastal forests in Hau Loc } \\
\text { district, Thanh Hoa province }\end{array}$ & $2016-2020$ & 228 & $\begin{array}{l}\text { Hau Loc district, Thanh Hoa } \\
\text { province }\end{array}$ \\
\hline 7 & $\begin{array}{l}\text { Community-Based Mangrove } \\
\text { Management Boards }\end{array}$ & $2007-2014$ & 458 & $\begin{array}{l}\text { Hau Loc and Nga Son district, } \\
\text { Thanh Hoa province }\end{array}$ \\
\hline
\end{tabular}

Sources: The Prime Minister (2015); Thanh Hoa DARD (2018).

In particular, from 2007-2014, CARE worked with local communities to apply an integrated, community-based approach to build coastal resilience, and in 2007, members of the community planted 277 ha of mangrove forests in Da Loc commune and 181 ha in Nga Thuy commune (belongs to Nga Son district) (Reed et al., 2015). Local people were encouraged to be engaged in planting, maintaining and protecting the young mangrove forests. For example, on one day, 700 local people took part in planting mangrove seedlings. This involvement contributed to raise local awareness of the importance of mangrove forests to their livelihoods and an increase of survival rate to $70 \div 90$ $\%$ of mangrove seedlings. Community participation initiatives have continuously contributed to improve mangrove forests and have flourished compared to earlier projects in the same area. This 
has created a major impact on the local communities since it was the first time that a 'nationwide mangrove forest decline' was finally reversed.

Despite these great achievements, community-based mangrove management institutions have been challenging with a high risk of closure in Da Loc and Nga Thuy. Both CMMBs have lacked the government's support and funding to keep the ongoing activities since 2014. CMMBs also have lack proper hierarchical methodology to ensure they had remained accountable. These issues also have hampered the efforts in developing community-based management in other districts and provinces.

During the period of 2015- April 2018:

A gradual increase of mangrove forests was experienced with additional 163 ha, equivalent to $47.8 \%$ of all mangrove areas. In particular, the project "Planting and restoration of coastal forests in Hau Loc district, Thanh Hoa province from 2016- 2020" in 2016 (Table 5) and another project "Strengthening the capacity of resistance to climate change for Nga Son and Hau Loc districts" in 2017 have significantly contributed to an increase of mangrove forests during the period of 20152018 (Table 5). However, there were also factors influencing the effectiveness of mangrove forests management this period. The poor leadership of CMMB has resulted in a dysfunctional manner of maintenance with the mangrove forests. In September 2017, typhoon Doksuri landed directly on Thanh Hoa coast, considered as one of the biggest storms in this region. Consequently, the storm disrupted the sedimentation process into mangrove forests, significantly resulted in the death of many mangrove trees.

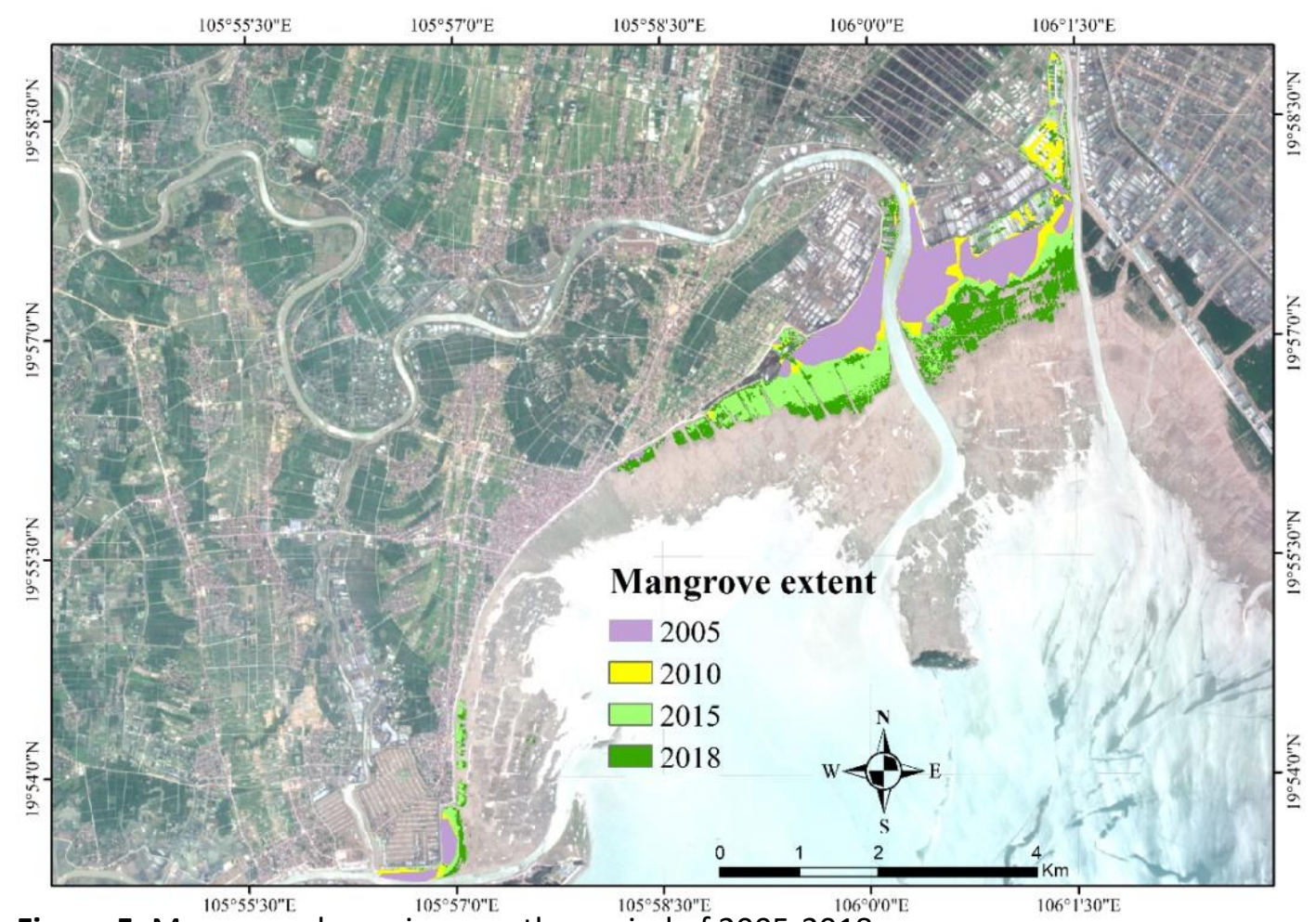

Figure 5. Mangrove dynamics over the period of 2005-2018.

In summary, by using the Landsat and Sentinel imageries to quantity changes in mangrove extents from 2005 to April 2018 (Figure 5), an overall finding shows that a large area of mangrove forests was observed with an increase of 278.0 ha during 2005- 2018 due to successful national programs of mangrove rehabilitation and restoration. A model of community-based mangrove management has also significantly contributed to an increase of mangrove extents. However, the loss of mangrove forests was still occurred in some places, resulting from the poor leadership capacity and extreme weather conditions. 


\section{Implications for sustainable management of mangrove forests in Thanh Hoa province}

In this study, mangrove forests have been recorded the increases during the period of 20052018 in Thanh Hoa province. Apart from good lessons learnt from Thanh Hoa for other coastal regions in Vietnam in terms of the community-based mangrove management in cooperation with local authorities; mangrove restoration and rehabilitation programs from both national and international supports, there are also some implications for enhancing mangrove management in Thanh Hoa as the following:

Enhancement of community-based mangrove management: Since the early 1990s, forest policy of allocating forestland to forest-adjacent people for management and development has been applied in Vietnam (Quang and Noriko, 2008), but it has not been applied for mangrove forests. The issues of mangrove management and restoration are being considered as the key adaptation strategies for mitigating climate change and coastal storm damages in Thanh Hoa province. For better management, a quick process implementation of allocation of mangrove forests to local residents and coastal communities should be taken into consideration to provide incentives to manage and protect mangrove forests at various levels (Kongwongjan et al., 2012; Datta et al., 2012; Phuc et al., 2013; Hai-Hoa, 2016). In particular, CBMM institutions should be restructured to ensure the local participation, which is based on user-decision making and mangrove resource sharing in both Nga Son and Hau Loc districts (Datta et al., 2012; Kongkeaw et al., 2019). Factors influencing the effectiveness of community based mangrove management, including leadership, occupational change, experience and capacity to organize into local groups, NGO support and increasing government support and recognition, should be taken seriously into the management process (Datta et al., 2012; Kongkeaw et al., 2019). In addition, mechanisms and policies on rights and responsibilities from mangrove management and protection should be clarified. Allocation priority should be given to local people according to the project and the plan approved by the associated authorities with certificates of land use rights (Hai-Hoa, 2016). However, mangrove allocation to households should not be applied nearby river mouths, estuaries or in front of the dike area and along the coast near residential areas that are more likely to be lost to avulsion and erosion. These areas should be handed over to local communities for common stewardship.

The cooperation system is one of the best solutions in the study areas where climatic conditions, economics, knowledge and traditional values are similar. Cooperation in mangrove protection and management should be applied between the CMMB groups; local commune mangrove forest protection station and public communication activities (Abdullah et al., 2014; Aheto et al., 2016; Kongkeaw et al., 2019).

Payment for forest environmental services (PFES) implementation: Local authorities and local households should be encouraged to participate in all REDD+ and PFES activities to receive additional financial support, which can enhance the effectiveness of CMMB model (Duke et al., 2010; Sommerville, 2016). Successful payment mechanisms from Lam Dong and Lai Chau provinces in Vietnam should be learned (Pham et al., 2013; Tredal and Vedeld, 2017). Benefits from PFES are also more likely to significantly improve local livelihoods, contributing to better mangrove protection and management. The management and administration schemes should be set up to encourage local people to protect and monitor mangrove resources (Pham et al., 2013; Phuc and Nghi, 2014).

\section{Conclusions}

This study used multi-temporal Landsat and Sentinel imageries to quantify changes of mangrove forests using 12 vegetation indices, Supervised and Unsupervised Classification methods in two districts of Thanh Hoa province, Vietnam. Sentinel 2A imagery in combination with PlanetScope imageries was tested to select the most suitable classification method for study sites. The result showed that the Supervised Classification method was the most suitable classification 
method due to the highest overall accuracy of $90.0 \%$. The study then quantified and constructed mangrove extents map in Hau Loc and Nga Son districts. As a result, mangrove forests gained about 278 ha (123.0 \%) over the last 13 years (from 2005 to 2018). The mangrove extents were quantified at 226.0 ha, 246.0, 341.0, and 504.0 ha in 2005, 2010, 2015 and 2018, respectively. Between 2005 and 2010 , the mangrove extents increased by approximately $7.5 \%$ due to mangrove plantation programs and CMMB implementation. The increment of the period from 2010 to 2015 was higher than other periods due to the improvement of $\mathrm{CMMB}$, which has encouraged local people to contribute to mangrove plantation and management. Since 2015, a gradual increase of mangrove extents was observed by $47.8 \%$, despite the projects on mangrove forests development for CMMB completed. The result of this study showed that $\mathrm{CMMB}$ was effective for mangrove planting and management, but facing with a risk of lacking funding support. Therefore, some lesson learnt are drawn to improve the management of mangrove forests in the study sites, including implementation of PFES, improvements of CBMM institutions and mangrove forest allocation.

\section{Acknowledgments}

This research is funded by Vietnam National Foundation for Science and Technology Development (NAFOSTED) under grant number 105.08-2017.05. The authors also would like to thank Commune's Red Cross and Commune People's Committee and local people in Nga Son and Hau Loc districts, Thanh Hoa province for supporting us when collecting data.

\section{Conflicts of interest}

The authors declare no conflict of interest.

\section{References}

Abdullah, K., Said, A. M., \& Omar, D. (2014). Community-based conservation in managing mangrove rehabilitation in Perak and Selangor. Procedia-Social and Behavioral Sciences, 153, 121-131. doi: https://doi.org/10.1016/j.sbspro.2014.10.047

Aheto, D. W., Kankam, S., Okyere, I., Mensah, E., Osman, A., Jonah, F. E., \& Mensah, J. C. (2016). Community-based mangrove forest management: Implications for local livelihoods and coastal resource conservation along the Volta estuary catchment area of Ghana. Ocean and Coastal Management, 127, 43-54. doi: https://doi.org/10.1016/j.ocecoaman.2016.04.006

Alsaaideh, B., Al-Hanbali, A., Tateishi, R., Kobayashi, T., \& Hoan, N. T. (2013). Mangrove forests mapping using Landsat ETM+ with DEM. Journal of Geographic Information System, 5, 369-377. doi: https://doi.org/10.4236/jgis.2013.54035

Agarwal, N., Bonino, C., Deligny, A., Festa, C., Ghislain, M., Homolova, K., Velasquez, A. K., Kurtev, L., Pinto, A. O., Virat, V., Serban-Penhoat, J., \& Thomas, M. (2019). Getting the shrimp's share mangrove deforestation and shrimp consumption assessment and alternatives. Sciences PoParis School of International Affairs (IDDRI), 102pp

Batadlan, B. D., Paringit, E. C., Santillan, J. R., Caparas, A. S., \& Fabila, J. L. (2009). Analysis of background variations in computed spectral vegetation indices and its implications for mapping mangrove forests using satellite imagery. In 4th ERDT Conference, Manila, Philippines.

Buffle, P., Nguyen, T. Y., \& Morten, F. T. (2011). Community-based Mangrove Reforestation and Management in Da Loc, Vietnam. Ecosystems and livelihoods adaptation network (ELAN). 11p

Chen, B., Xiao, X., Li, X., Pan, X., Doughty, R., Ma, J., Dong, J., Qin, Y., Zhao, B., Wu, Z., Sun, R., Lan, G., Xie, G., Clinton, N., \& Giri, C. (2017). A mangrove forest map of China in 2015: Analysis of time series Landsat $7 / 8$ and Sentinel $1 \mathrm{~A}$ imagery in Google Earth Engine cloud computing platform. ISPRS Journal of Photogrammetry and Remote Sensing. 131, 104- 210. doi: https://doi.org/10.1016/j.isprsjprs.2017.07.011

Dat, P. T., Yoshino, K., Le, N. N., \& Bui, D. T. (2018). Estimating aboveground biomass of a mangrove plantation 
on the Northern coast of Vietnam using machine learning techniques with an integration of ALOS-2 PALSAR-2 and Sentinel-2A data. International Journal of Remote Sensing, 39(22), 7761-7788. doi: https://doi.org/10.1080/01431161.2018.1471544

Dat, P. T., Anh, N. K., \& Yoshino, K. (2000). Mapping wetland cover types using remote sensing and GIS in Can Gio Mangrove Biosphere Reserve, Vietnam. Lecture note in Earth Science: 66-74

Datta, D., Chattopadhyyay, R. N., \& Guha, P. (2012). Community based mangrove management: a review on status and sustainability. Journal of Environmental Management, 107, 84-95. doi: https://doi.org/10.1016/j.jenvman.2012.04.013

Duke, N., Nagelkerken, I., Agardy, T., Wells, S., \& Van Lavieren, H. (2014). The importance of mangroves to people: a call to action. United Nations Environment Programme World Conservation Monitoring Centre (UNEP-WCMC3). 128pp

Duke, N., Wilson, N., Mackenzie, J. R., Hai-Hoa, N., \& Pullar, D. (2010). Assessing mangrove forests, shoreline condition and feasibility of REDD for Kien Giang province, Vietnam. Technical Report. 137pp. doi: 10.13140/RG.2.1.1032.5367

Exner, A., Fleissner, P., Kranzl, L., \& Zitel, W. (2014). Land and resource scarcity: Capitalism, struggle and well-being in a world without fossil fuels. Routledge Taylor and Francis Group. 320pp

Field, C., Osborn, J., Hoffman, L., Polsenberg, J., Ackerly, D., Berry, J., Bjorkman, O., Held, A., Matson, P., \& Mooney, H. (1998). Mangrove biodiversity and ecosystem function. Global Ecology \& Biogeography Letters, 7(1), 3-14. doi: 10.2307/2997693

Green, E. P., Clark, C. D., Mumby, P. J., Edwards, A. J., \& Ellis, A. C. (1998). Remote sensing techniques for mangrove mapping. International Journal of Remote Sensing, 19(5), 935-956. doi: https://doi.org/10.1080/014311698215801

Gupta, K., Mukhopadhyay, A., Giri, S., Chanda, A., Majumdar, S. D., Samanta, S., \& Hazra, S. (2018). An index for discrimination of mangroves from non-mangroves using LANDSAT 8 OLI imagery. MethodsX, 5, 1129-1139. doi:https://doi.org/10.1016/j.mex.2018.09.011

Ha,T. T., Van, D. P. H., \& Visser, L. (2014). Impacts of changes in mangrove forest management practices on forest accessibility and livelihood: A case study in mangrove-shrimp farming system in Ca Mau Province, Mekong Delta, Vietnam. Land Use Policy, 36, 89-101. doi: https://doi.org/10.1016/j.landusepol.2013.07.002

Hai-Hoa, N. (2016). Using Landsat imagery and vegetation indices differencing to detect mangrove change: A case in Thai Thuy district, Thai Binh province. Journal of Forest Science and Technology, 5, 59-66.

Hai-Hoa, N. (2014). The relation of coastal mangrove changes and adjacent land-use: A review in Southeast Asia and Kien Giang, Vietnam. Ocean and Coastal Management, 90, 1-10. doi: https://doi.org/10.1016/j.ocecoaman.2013.12.016

Hawkins, S., To, P. X., Phuong, P. X., Thuy, P. T., Tu, N. D., Cuong, C. V., Brown, S., Dart, P., Robertson, S. M., Vu, N., \& McNally, R. (2010). Roots in the Water: Legal Frameworks for Mangrove PES in Vietnam. Katoomba Group's Legal Initiative Country Study Series. Forest Trends: Washington, DC. $55 p p$

Hoa, S. L. T., Suzuki, R., \& Thomsen, M. F. (2012). Adapting to natural disasters and contributing to climate change mitigation: mangrove community forestry in Viet Nam. Sharing Lessons on Mangrove Restoration. Proceedings and a Call Action from an MFF Regional Colloquium 30- 31 August 2012, Mamallapuram, India, 265-275.

Hong, P. N., \& San, H. T. (1993). Mangroves of Vietnam. IUCN, Vol. 7.

Islam, M. M., Borgqvist, H., \& Kumar, L. (2018). Monitoring mangrove forest land cover changes in the coastline of Bangladesh from 1976 to 2015. Geocarto International, 34(13), 1458-1476. doi: https://doi.org/10.1080/10106049.2018.1489423

International Federation of Red Cross and Red Crescent Societies. (2011). Breaking the waves: Impact analysis of coastal afforestation for disaster risk reduction in Vietnam. 60pp

Jiang, Z., Raghavan, S. V., Hur, J., Sun, Y., Liong, S., Nguyen, V. Q., \& Dang, T. V. P. (2018). Future 
changes in rice yields over the Mekong River Delta due to climate change- alarming or alerting? Theoretical and Applied Climatology, 137, 545- 555. doi:https://doi.org/10.1007/s00704-0182617-z

Kongwongjan, J., Suwanprasit, C., \& Thongchumnum, P. (2012). Comparison of vegetation indices for mangrove mapping using THEOS data. Proceedings of the Asia-Pacific Advanced Network, $33,56-64$.

Kongkeaw, C., Kittitornkool, J., Vadergeest, P., \& Kittiwatanawong, K. (2019). Explaining success in community based mangrove management: Four coastal communities along the Andaman Sea, Thailand. Ocean and Coastal Management, 178, doi: https://doi.org/10.1016/j.ocecoaman.2019.104822

Lee, S. Y., Primavera, J. H., Dahdouh-Guesbas, F., Mckee, K., Bosire, J. O., Cannicci, S., \& Mendelssohn, I. (2014). Ecological role and services of tropical mangrove ecosystems: A reassessment. Global Ecology and Biogeography, 23(7), 726-743. doi:https://doi.org/10.1111/geb.12155

Li, P., Jiang, L., \& Feng, Z. (2013). Cross-comparison of vegetation indices derived from Landsat-7 enhanced thematic mapper plus (ETM+) and Landsat-8 operational land imager (OLI) sensors. Remote Sensing, 6(1), 310-329. doi: https://doi.org/10.3390/rs6010310

Long, J. B., \& Giri, C. (2011). Mapping the Philippines' mangrove forests using Landsat imagery. Sensors, 11(3), 2972-2981. doi: https://doi.org/10.3390/s110302972

Lu, D., Mausel, P., Brondizio, E., \& Morab, E. (2004). Change detection techniques. International Journal of Remote Sensing, 25(12), 2365-2401. doi: https://doi.org/10.1080/0143116031000139863

Muhsoni, F. F., Sambah, A., Mahmudi, M., \& Wiadnya, D. (2018). Comparison of different vegetation indices for assessing mangrove density using sentinel-2 imagery. Int. J. Geomate, 14, 42-51. doi: https://doi.org/10.21660/2018.45.7177

Norjamaki, I., \& Tokola, T. (2007). Comparison of atmospheric correction methods in mapping timber volume with multi-temporal Landsat images in Kainuu, Finland. Photogrammetric Engineering \& Remote Sensing, 73(2), 155-163. doi: https://doi.org/10.14358/PERS.73.2.155

Peneva-Reed, E. (2014). Understanding land-cover change dynamics of a mangrove ecosystem at the village level in Krabi Province, Thailand, using Landsat data. GIScience \& Remote Sensing, 51(4), 403-426. doi: https://doi.org/10.1080/15481603.2014.936669

Pham, T. T., Bennet, K., Vu, T. P., Brunner, J., Le, N. D., \& Nguyen, D. T. (2013). Payments for forest environmental services in Vietnam: from policy to practice. Occasional Paper 93. Bogor, Indonesia, CIFOR. 96pp

Phuc, T. X., Nghi, T. H., \& Zagt, R. (2013). Forest land allocation in Viet Nam: implementation processes and results. Tropenbos International Vietnam: 1-10.

Phuc, T. X., \& Nghi, T. H. (2014). Forest land allocation in the context of forestry sector restructuring: opportunities for forestry development and upland livelihood improvement, Vietnam. Tropenbos International Vietnam. 86pp

Primavera, J. H. (2000). Development, and conservation of Philippine mangroves: institutional issues. Ecological Economics, 35(1), 91-106. doi: https://doi.org/10.1016/S09218009(00)00170-1

The Prime Minister. (2015). Approving the project on protection and development of coastal forests to cope with climate change in 2015-2020 period. Decision No 120/QÐ-Ttg, dated 22 January 2015. 32pp

Quang, N. V., \& Noriko, S. (2008). Forest allocation policy and level of forest dependency of economic household groups: A case study in northern central Vietnam. Small-scale Forestry, 7(1), 49-66. doi:https://doi.org/10.1007/s11842-008-9040-8

Raghavan, S. V., Vu, M. T., \& Liong, S. Y. (2015). Regional climate simulations over Vietnam using the WRF model. Theoretical and Applied Climatology, 126(1-2), 161-182. doi: 
https://doi.org/10.1007/s00704-015-1557-0

Ramdani, F., Rahman, S., \& Giri, C. (2018). Principal polar spectral indices for mapping mangroves forest in South East Asia: study case Indonesia. International Journal of Digital Earth, 12, 11031117. doi: https://doi.org/10.1080/17538947.2018.1454516

Rogan, J., \& Chen, D. (2004). Remote sensing technology for mapping and monitoring land-cover and land-use change. Progress in Planning, 61(4), 301-325. doi: https://doi.org/10.1016/S03059006(03)00066-7

Reed, S. O., Nghi, N. V., Minh, N. A., Lien, H. T. K., Hung, T. M., Thien, N. V., \& Anh, N. K. (2015). Building Coastal Resilience in Vietnam: An integrated, community-based approach to mangrove management, disaster risk reduction, and climate change adaptation. CARE international in Vietnam. 80pp

Richards, D. R., \& Friess, D. A. (2016). Rates and Drivers of mangrove deforestation in Southeast Asia, 2000- 2012. Proceedings of the National Academy of Sciences of the United States of America (PNAS), 113(2), 344-349. doi:https://doi.org/10.1073/pnas.1510272113

Salem, M. E., \& Mercer, D. E. (2012). The economic value of mangroves: A meta-analysis. Sustainability, 4(3), 359-383. doi: https://doi.org/10.3390/su4030359

Saleh, M. (2007). Mangrove vegetation on Abu Minqar Island of the Red Sea. International Journal of Remote Sensing, 28(23), 5191-5194. doi:https://doi.org/10.1016/j.jaridenv.2006.05.016

Singh, A. (1989). Review article digital change detection techniques using remotely-sensed data. International Journal of Remote Sensing, 10(6), 989-1003. doi:https://doi.org/10.1080/01431168908903939

Song, C., Woodcock, C. E., Seto, K. C., Lenney, M. P., \& Macomber, S. A. (2001). Classification and change detection using Landsat TM data: when and how to correct atmospheric effects. Remote Sensing of Environment, 75(2), 230-244. doi: https://doi.org/10.1016/S0034-4257(00)00169-3

Sommerville, M. (2016). Mangrove payment for environmental services in Vietnam: Opportunities and challenges. Washington, DC: USAID Tenure and Global Climate Change Program. 34pp

Thanh Hoa DARD (Department of Agriculture and Rural Development). (2018). Reviewing coastal mangrove forest land in districts to participate in projects to restore and develop coastal protective forests. Report No.62/BC-SNN\&PTNT (In Vietnamese).

Tran Thi, V., Tien Thi Xuan, A., Phan Nguyen, H., Dahdouh, F., \& Koedam, N. (2014). Application of remote sensing and GIS for detection of long-term mangrove shoreline changes in Mui Ca Mau, Vietnam. Biogeosciences, 11, 3781-3795. doi: https://doi.org/10.5194/bg-11-3781-2014

Treadal, L. T., \& Vedeld, P. O. (2017). Livelihoods and land uses in environmental policy approaches: the case of PES and REDD+ in the Lam Dong province of Vietnam. Forest, 8, 39. doi: https://doi.org/10.3390/f8020039

Van Lavieren, H., Spalding, M., Alongi, D. M., Kainuma, M., Clusener-Godt, M., \& Adeel, Z. (2012). Securing the future of mangroves. A policy brief. UNU-INWEH, UNESCO-MAB with ISME, ITTO, FAO, UNEP-WCMC and TNC. 53pp

Viswanathan, P. K., Pathak, K. D., \& Mehta, I. (2011). Socio-economic and ecological benefits of mangrove plantation: A study of community based mangrove restoration activities in Gujarat. Gujarat Institute of Development Research. 164p.

Wang, F. M., Huang, J. F., Tang, Y. L., \& Wang, X. Z. (2007). New vegetation index and its application in estimating leaf area index of rice. Rice Science, 14(3), 195-203. doi: https://doi.org/10.1016/S1672-6308(07)60027-4

Wang, Y., Bonynge, G., Nugranad, J., Traber, M., Ngusaru, A., Tobey, J., \& Makota, V. (2003). Remote sensing of mangrove change along the Tanzania coast. Marine Geodesy. 26(1-2), 35-48. doi: https://doi.org/10.1080/01490410390181243

Xia, Q., Qin, C., Li, H., Huang, C., \& Su, F. (2018). Mapping mangrove forests based on multi-tidal high resolution satellite imagery. Remote Sens, 10, 1343. doi:https://doi.org/10.3390/rs10091343

Zhang, X., Treitz, P. M., Chen, D., Quan, C., Shi, L., Li, Z. (2017). Mapping mangrove forests using 
multi-tidal remotely-sensed data and a decision-tree based procedure. Int J Appl Earth Obs Geoinformation, 62, 201-214. doi:https://doi.org/10.1016/j.jag.2017.06.010

Zhang, K., Dong, X., Liu, Z., Gao, W., Hu, Z., \& Wu, G. (2019). Mapping flats with Landsat 8 images and Google Earth Engine: A case study of the China's Eastern coast zone circa 2015. Remote Sensing, 11, 924. doi: https://doi.org/10.3390/rs11080924 